\title{
MEASUREMENT AND DRIVING FACTORS OF THREE-DIMENSIONAL ECOLOGICAL FOOTPRINT IN SHENYANG CITY
}

\author{
Tongfeng $\mathrm{CHEN}^{1,2}, \mathrm{Ke} \mathrm{CHEN}^{1 *}$ and Chang $\mathrm{WANG}^{2}$
}

${ }^{1}$ School of Economics and Management, Shenyang Agricultural University, Shenyang 110866, China

${ }^{2}$ School of Economics and Management, Suzhou University, Suzhou city 234000

*Autor de correspondencia: chenkeyaya@163.com

(Received June 2018; accepted July 2018)

Key words: Shenyang city, three dimensional ecological footprint, footprint depth, footprint breadth, partial least-squares regression

\begin{abstract}
Based on the three-dimensional (3D) ecological footprint model, this paper has provided the measurements of the dynamic changes of the 3D ecological footprint of Shenyang from 2005 to 2016, and the analysis of the driving factors behind such footprint through the partial least-squares regression. Our research findings reveal that: The overall per capita 3D ecological footprint of the Shenyang City went upward from 2005 to 2016, with an average annual growth rate of $16.5 \%$; at the meantime, the per capita ecological carrying capacity showed a year-on-year downward trend at an average annual rate of $0.79 \%$. The analysis of partial least squares regression indicates that urban ecological construction and environmental pollution constitute the significant factors that lead to the increase of the ecological footprint year by year in Shenyang. On the contrary, the exchange and trade, the environmental governance and the structure of land use are conducive to relieving the pressure on the ecological expansion. Our analysis of the importance of variable projections demonstrates that per capita public green area and the emission indicators of the industrial waste have imposed a greater influence on the index of ecological footprint of Shenyang and are relatively consistent with the comprehensive evaluation results of the regression analysis. In the future, we shall enhance the efficiency of urban ecological construction by optimizing industrial structure, using clean energy, actively developing foreign trade and exchanges, and rationally planning urban land use.
\end{abstract}

Palabras clave: ciudad de Shenyang, huella ecológica tridimensional, profundidad de huella ecológica, amplitud de huella ecológica, regresión de mínimos cuadrados parciales

\section{RESUMEN}

Con base en el modelo tridimensional (3D) de huella ecológica, este trabajo proporciona las mediciones de los cambios de la huella ecológica 3D en Shenyang de 2005 a 2016 y el análisis de los factores impulsores de dicha huella por medio de un análisis de regresión de mínimos cuadrados parciales. Nuestros hallazgos de investigación revelan que la huella ecológica 3D total per cápita en la ciudad de Shenyang se incrementó de 2005 a 2016 con una tasa de crecimiento anual promedio de $16.5 \%$; al mismo 
tiempo, la capacidad de carga ecológica per cápita mostró una tendencia decreciente a una tasa anual promedio de $0.79 \%$. El análisis de regresión de mínimos cuadrados parciales indica que la construcción urbana ecológica y la contaminación ambiental son los factores significativos que llevan al incremento anual de la huella ecológica en Shenyang. Por el contrario, el intercambio, el comercio, la gobernanza ambiental y la estructura del uso del suelo liberan la presión sobre la expansión ecológica. Nuestro análisis de la importancia de las proyecciones variables demuestra que el área pública verde per cápita y los indicadores de emisión de desechos industriales han tenido gran influencia en el índice de la huella ecológica en Shenyang y son relativamente consistentes con la evaluación comprensiva de los resultados del análisis de regresión. En el futuro destacaremos la eficiencia de la construcción urbana ecológica optimizando la estructura industrial, usando energía limpia y desarrollando activamente el intercambio y comercio extranjero, así como la planeación urbana y el uso del suelo racionales.

\section{INTRODUCTION}

Sustainability, which refers to the sustainable use of natural capital, lies at the core of the regional development. However, in many of the quantitative studies of regional sustainable development, the ecological footprint model has found the widest application. The concept of ecological footprint was originally proposed by William Rees and eventually evolved into a classic model by a group researcher, namely, the ecological footprint model. The model was first introduced into China by some group researchers and was adopted in the studies of various industries such as energy, water resources, tourism, restaurants, and residential living and consumption (Fu and Liu 2017, Gao and Wang 2017, Grzeczka and Szymak 2016, Xu et al. 2001, Nordin et al. 2017, Roslan et al. 2017). However, the spatial and temporal dynamic evolution of the ecological footprint in long-term sequence specific to regions has been the current research hotspot in terms of the research scale. Domestically, several researchers have studied the ecological footprint of the Gansu Province from 1996 to 2009 by using the grey relational model (Hui et al. 2013). During one of such studies, the researchers studied the ecological footprint of China in 2007 by proposing an index for the balance between the ecological supply and demand (Dong et al. 2012). In foreign countries, Niccolucci divided the sustainable development of different countries into several typical forms (Niccolucci et al. 2009, Mana et al. 2017). One researcher has studied the land use demand of Australians in the past 75 years through the ecological footprint model (Erb 2004). Currently, all of the ecological footprint models (hereinafter referred to as classical models) are based on the ecological footprint and ecological carrying capacity (2D perspective). The new 3D ecological footprint model (hereinafter referred to as the 3D model) is used to illustrate the dynamic changes of Xilin Gol League natural capital. The 3D model was initially proposed by a group researcher, and the model was introduced and optimized by the Chinese scholar Fang Kai before being widely studied and applied (Niccolucci et al. 2012, Borogayary et al. 2018, Pe'Eri et al. 2016, Ahamed et al. 2017, Cheung et al. 2017). Some researchers adopted the model to measure the natural capital of Beijing-Tianjin-Hebei urban agglomeration (Du et al. 2016, Yun et al. 2018, Toum et al. 2018). In other studies, researchers extended the 3D ecological footprint model to study the land carrying capacity of the Wenzhou City, and this paper attempts to build on the 3D ecological footprint model (Jin and Liu 2017). Footprint breadth and footprint depth are used to analyze the utilization of natural capital stocks and flow rate in Shenyang, and an indicator system is proposed for measuring the impact factor of the three-dimensional ecological footprint in Shenyang. In addition, the partial least-squares regression is used to analyze the impact of the target layer. Through the importance of projection, the contribution rate of each index layer to the ecological footprint has been analyzed to diagnose the shortcomings and negative factors leading to the exacerbating ecological imbalance in Shenyang. The paper intends to provide operable suggestions and future initiatives for achieving the transition of Shenyang into an ecological city through the sustainable development (SMBS 2017).

\section{MATERIAL AND METHODS}

\section{Research methodology \\ Three-dimensional ecological footprint model}

The original ecological footprint model is derived from the addition of ecological capacity and 
ecological deficits. The improved 3D model regards the ecological footprint as a cylinder: the bottom surface corresponds to the breadth of the footprint; the height of the cylinder represents the depth of the footprint, and the $3 \mathrm{D}$ ecological footprint is multiplied by the breadth and the depth of the footprint. The depth of per capita footprint refers to the multiple of the per capita land area necessary for maintaining the current level of consumption. The larger the value is observed, the greater the ecological deficit will be generated, which suggests the diminished sustainablity. The scope of per capita footprint refers to the area of bio-producing land that is occupied by the population within the average of per capita ecological carrying capacity, which is used to represent the level of per natural capita flow in the region. Its calculation formula is shown as follows:

$\mathrm{ef}_{\text {depth }}=1+\mathrm{ed} / \mathrm{ec}$

$e f_{\text {size }}=\min (e f, e c)$

$\mathrm{EF}=\mathrm{ef}_{\text {depth }} \times \mathrm{ef}_{\text {size }}$

ef depth refers to the footprint depth (dimensionless); ef size refers to the footprint width $\left(\mathrm{hm}^{2} /\right.$ person); ef refers to the average per capita ecological footprint $\left(\mathrm{hm}^{2} /\right.$ person); ed refers to per capita ecological deficit ( $\mathrm{hm}^{2} /$ person); ec refers to per capita ecological bearing capacity ( $\mathrm{hm}^{2} /$ person); and EF refers to per capita 3D ecological footprint ( $\mathrm{hm}^{2} /$ person).

\section{Partial least squares regression}

The values of each indicator reflect the importance degree of the impact on the ecological footprint and can effectively identify such impact in the regression factors. When conducting the analysis of the variable projection importance, the researchers have adopted the partial least-squares regression. The formula is shown as follows:

$V I P_{j}=\sqrt{\frac{p \sum_{k=1}^{m} R d\left(Y ; t_{h}\right) w_{k j}^{2}}{R d\left(Y ; t_{1}, \cdots, t_{m}\right)}}$

Where: VIP $_{j}$ refers to the VIP value of the $j^{\text {th }}$ index, $\mathrm{p}$ refers to the number of selected indicator variables, $\mathrm{m}$ represents the logarithm of the PLS principal component extracted, and $\mathrm{Rd}(\mathrm{Y} ; \mathrm{t} 1, \ldots, \mathrm{tm})$ defines the cumulative explanatory power of the axis $t_{1}, \ldots, t_{m}$ on $Y, R d(Y ; t h)$ refers to the ability of the axis $t_{h}$ to interpret $Y$. Generally, some researchers believe that indicators with a VIP value greater than 1 are important influencing factors; indicators with a VIP value between 0.8 and 1 are less important; and VIP values below 0.8 are considered to be the least important (Wang et al. 2016, Ashraf et al. 2017).

\section{Sources and processing of the data}

The biogenic soil surface of the ecological footprint is calculated from the cultivated land, forest land, grassland, water area, construction land, and fossil fuel land. For the sake of safeguarding the ecological environment, $12 \%$ of the ecological capacity needs to be reserved for the protection of biodiversity. This share of the capacity is required to be deducted from the ecological capacity for the measurement to be realistic. Regarding the land use in the micro- and macro-regions, southern and northern cities also vary from each other. Various types of land are adjusted as follows: Due to the underdeveloped sector of the animal husbandry in Shenyang, the grassland species that yield products for the sector are too limited to be ignored. Since the urban green space is used to absorb urban pollution and waste, it is different from the traditional types of using forest land (Aness et al. 2017). Therefore, the land used for forests and grassland shall be integrated into the urban green space for inspection. The garden serves as the transitional land of cultivated land and woodland, and the products of the garden are mainly the fruits grown in it, whereas the main function of urban woodland is afforestation. Therefore, the researchers have separated the analysis of the garden from that of the forest land (Lijie and Feng 2018, Basheer et al. 2017). The equilibrium factor and production factor constitute the average values measured in the cultivated land and the forest land. Neither the ecological deficits nor the ecological surpluses between different types of land may offset and superimpose each other. Even though a surplus is observed, it cannot compensate for deficits in other types of land. Therefore, the ecological deficit in this category is defined as 0 , which can reflect the class of total ecological footprint in a more accurate way.

The calculation of the ecological footprint mainly includes the accounts of biological resources and energy resources. Among them, the account of biological resources has 28 production items such as grain and cotton, and the account of energy resources mainly includes 14 kinds of consumption items such as raw coal and clean coal. The data is drawn from the statistics released by the Shenyang Municipality from 2006 to 2016. The average production data for all types of productions comes from the Living Planet 
Report (WWF) of the World-Wide Fund for Nature (WWF 2013). The equilibrium factors and production factors come from the reports of ecological footprint released by various countries around the world, and various energy conversion coefficients refer to the "China Energy Statistical Yearbook" (2006-2016) (SMBS 2017).

\section{RESULTS}

\section{Depth of per capita ecological footprint in Shen- yang}

From formula (1), we can calculate the depth of ecological footprints in various regions as shown in Table I. The data indicate that the footprint depth of the arable land in Shenyang City from 2006 to 2016 has shown a decreasing trend, which is mainly driven by the increase in the yield per unit of grain due to enhanced technologies and increased use of agricultural machinery. The average annual decline rate of the footprint of green land amounts to $22.47 \%$, but there is still a greater pressure on the ecological environment. The garden footprint depth has always been one because the ecological carrying capacity of the garden is greater than its ecological footprint and there is an ecological surplus. However, the surplus cannot compensate for the ecological deficits of other types of land. In 2016, the water footprint depth amounted to as high as 48.59 , indicating that the Shenyang City would require almost 49 times of the current water area to meet the demand of the population. Judging from our statistics, the population of the Shenyang City has excessively used the natural capital stock of waters, and the production and the development of the City are the least sustainable among our surveyed regions. The footprint depth of the building land shows an "inverted U" curve, and the total size is increasing. In 2016, there still had to be 3.168 times of the construction land area in the Shenyang City to meet the needs of the population. Our findings reveal that in order to maintain the current consumption level of the population in Shenyang, there will have to be 2.489 times of cultivated area, 3.05 times of green area, 48.61 times of water area, 3.168 times of building area and 3.839 times of energy land in Shenyang to basically achieve the balance of the City's ecological environment and the sustainable development of its society.

\section{Per capita ecological footprint of Shenyang}

Based on formula (2), we can calculate the breadth of ecological footprints in various parts of Shenyang as shown in Table II. In terms of the composition of the footprint breadth, the arable land footprint in 2016 accounted for $59.29 \%$; the construction land accounted for $33.38 \%$; the green space accounted for $4.696 \%$; the water area accounted for $2.19 \%$; and the garden accounted for $0.399 \%$. Judging from the aforementioned proportion, we may conclude that the arable land and the construction land constitute the main parts, followed by the green space, water area and garden area. This demonstrates that the per capita land occupation area in the Shenyang City is dominated by the arable land and the construction land. From the perspective of time series, the breadth of the arable land tends to decrease, which is mainly driven by the year-by-year reduction in the area of arable land. The breadth of per capita footprint of the construction land experienced an increase, followed by a decline and then again an increase due to the accelerated urbanization drive. The green

TABLE I. THE PER CAPITA ECOLOGICAL FOOTPRINT DEPTH OF SHENYANG CITY DURING 2006-2016

\begin{tabular}{lcccccc}
\hline Year & Arable land & Green land & Garden & Sea & Building land & Fossil energy \\
\hline 2006 & 2.8699 & 5.5467 & 1 & 30.7672 & 1.1299 & 2.0769 \\
2007 & 3.1023 & 5.1349 & 1 & 39.4159 & 1.5561 & 1.6259 \\
2008 & 2.9689 & 4.9371 & 1 & 41.1674 & 1.6183 & 2.4341 \\
2009 & 3.0376 & 4.7111 & 1 & 43.2891 & 1.6723 & 2.7149 \\
2010 & 2.8812 & 4.6244 & 1 & 43.5812 & 2.6455 & 3.0774 \\
2011 & 2.9876 & 4.5899 & 1 & 45.8811 & 2.6941 & 3.1799 \\
2012 & 2.5211 & 3.4812 & 1 & 45.4118 & 3.0361 & 3.3151 \\
2013 & 2.3513 & 3.3191 & 1 & 49.2277 & 3.1158 & 3.1872 \\
2014 & 2.5214 & 3.0292 & 1 & 49.0969 & 3.2711 & 3.3412 \\
2015 & 2.4976 & 3.0463 & 1 & 48.7921 & 3.2563 & 3.6210 \\
2016 & 2.4988 & 3.0579 & 1 & 48.5881 & 3.1677 & 3.8412 \\
\hline
\end{tabular}


TABLE II. THE PER CAPITA ECOLOGICAL FOOTPRINT SIZE OF SHENYANG CITY DURING 2006-2016

\begin{tabular}{lcccccc}
\hline Year & Arable land & Green land & Garden & Sea & Building land & Fossil energy \\
\hline 2006 & 0.2680 & 0.0141 & 0.0049 & 0.0094 & 0.0865 & 1 \\
2007 & 0.2589 & 0.0158 & 0.0059 & 0.0082 & 0.0912 & 1 \\
2008 & 0.2385 & 0.0158 & 0.0059 & 0.0075 & 0.0949 & 1 \\
2009 & 0.2301 & 0.0157 & 0.0079 & 0.0073 & 0.0956 & 1 \\
2010 & 0.2258 & 0.0153 & 0.0059 & 0.0071 & 0.0952 & 1 \\
2011 & 0.1922 & 0.0150 & 0.0007 & 0.0070 & 0.0950 & 1 \\
2012 & 0.1844 & 0.0148 & 0.0009 & 0.0069 & 0.0948 & 1 \\
2013 & 0.1902 & 0.0146 & 0.0012 & 0.0068 & 0.0951 & 1 \\
2014 & 0.1847 & 0.0144 & 0.0013 & 0.0067 & 0.0953 & 1 \\
2015 & 0.1797 & 0.0143 & 0.0012 & 0.0067 & 0.0971 & 1 \\
2016 & 0.1771 & 0.0141 & 0.0013 & 0.0066 & 0.0998 & 1 \\
\hline
\end{tabular}

space footprint showed an "inverted U" curve, which peaked in 2006-2008, and then experienced a continuous decline. This was mainly due to the increase in population and the annual decrease in the area of green space. In addition, the ecological footprint of the garden is much smaller than the ecological carrying capacity, leading to an ecological surplus. Consequently, the carrying capacity of the garden in 2016 is about seven times that of its footprint, eliminating the possibility of an ecological deficit in the short term. As the ecological carrying capacity of the energy land is 0 , the ecological footprint is shown as the ecological deficit. Formulas (1) and (2) are not applicable to this type of land, and its 3D ecological footprint is consistent with the traditional algorithm.

\section{Per capita 3D ecological footprint in Shenyang}

Based on formula (3), the 3D ecological footprints of various cities are calculated in the Shenyang City, as shown in Table III. In 2016, the per capita 3D ecological footprint of the City amounted to 4.9591 $\mathrm{hm}^{2} /$ person, with a per capita capacity of $0.3043 \mathrm{hm}^{2} /$ person and an ecological deficit of $4.6548 \mathrm{hm}^{2} /$ person (Daly 1994). The per capita ecological footprint of Shenyang is about 16.3 times that of its per capita ecological capacity, imposing a significant ecological pressure. If the population of the Shenyang City is to maintain its current consumption level, the socialeconomic development of the City will have to be rely primarily on depleting the natural capital of its surrounding areas. (Farly and Daly, 2006). At least, the City will require the equivalent of 16 bio-producing areas in its global average space. Judging from Table III, we can see that the energy footprint of 2006-2016 has been the leading part of the 3D ecological footprint of the Shenyang City, and it is consistent with the overall ecological footprint (Fang 2013). This is because Shenyang is a typical comprehensive industrial city dependent on the resourceconsuming and heavy chemical industry. As the City

TABLE III. THE PER CAPITA ECOLOGICAL FOOTPRINT OF THE SHENYANG CITY FROM 2006 TO 2016 HM²/PERSON

\begin{tabular}{cccccccccc}
\hline Year & $\begin{array}{c}\text { Arable } \\
\text { land }\end{array}$ & $\begin{array}{c}\text { Forest } \\
\text { land }\end{array}$ & Grassland & $\begin{array}{c}\text { Water } \\
\text { area }\end{array}$ & $\begin{array}{c}\text { Building } \\
\text { land }\end{array}$ & $\begin{array}{c}\text { Energy } \\
\text { land }\end{array}$ & $\begin{array}{c}\text { 3D } \\
\text { footprint }\end{array}$ & $\begin{array}{c}\text { Per capita ecological Per capita ecological } \\
\text { carrying capacity }\end{array}$ \\
\hline 2006 & 0.7691 & 0.0782 & 0.0049 & 0.2892 & 0.0977 & 2.0769 & 3.3161 & 0.3793 & 2.9368 \\
2007 & 0.8032 & 0.0811 & 0.0059 & 0.3232 & 0.1419 & 1.6259 & 2.9812 & 0.3781 & 2.6031 \\
2008 & 0.7081 & 0.0780 & 0.0059 & 0.3088 & 0.1536 & 2.4341 & 3.6884 & 0.3616 & 3.3268 \\
2009 & 0.6990 & 0.0740 & 0.0079 & 0.3160 & 0.1599 & 2.7149 & 3.9716 & 0.3530 & 3.6186 \\
2010 & 0.6506 & 0.0708 & 0.0059 & 0.3094 & 0.2519 & 3.0774 & 4.3659 & 0.3482 & 4.0177 \\
2011 & 0.5742 & 0.0688 & 0.0007 & 0.3212 & 0.2559 & 3.1799 & 4.4008 & 0.3141 & 4.0867 \\
2012 & 0.4649 & 0.0515 & 0.0009 & 0.3133 & 0.2878 & 3.3151 & 4.4336 & 0.3059 & 4.1277 \\
2013 & 0.4472 & 0.0485 & 0.0012 & 0.3347 & 0.2963 & 3.1872 & 4.3151 & 0.3125 & 4.0026 \\
2014 & 0.4657 & 0.0436 & 0.0013 & 0.3289 & 0.3117 & 3.3412 & 4.4925 & 0.3079 & 4.1846 \\
2015 & 0.4488 & 0.0436 & 0.0012 & 0.3269 & 0.3162 & 3.6210 & 4.7577 & 0.3045 & 4.4532 \\
2016 & 0.4425 & 0.0431 & 0.0013 & 0.3207 & 0.3161 & 3.8412 & 4.9650 & 0.3044 & 4.6606 \\
\hline
\end{tabular}


achieves the economic growth and the continuously advanced urbanization while suffering from the diminished energy efficiency, it has experienced huge level of energy consumption. The arable land footprint was on the decline from 2006 to 2016, mainly due to the reduction of arable land. The footprint of the water area did not change much despite some fluctuations. The foothold of the construction land has been slowly on the rise, but there has been a sudden change from 2009 to 2010, which was mainly driven by the space expansion of the City and the corresponding needs of developing and utilizing its land (Fang 2014). From 2006 to 2016, the per capita ecological carrying capacity continued to decline, which was primarily related to economic development, urban expansion and population growth, while the ecological deficit was basically consistent with the ecological footprint.

\section{DISCUSSION}

\section{Selection of influencing factors}

The ecological footprint reflects the extent of regional sustainable development and the utilization of resources. The footprint is directly or indirectly related with the social and economic development of the region (Costanza and Daly 1992). Therefore, this article refers to the selection of the influencing factors for the existing ecological footprint, comprehensively considers economic, social, environmental, and population aspects, and establishes an index system of the influencing factors for the ecological footprint, including 8 target layers and 36 indicator layers. Each indicator is calculated from the data derived from the Statistical Yearbook of Shenyang, and the weight of each target sub-indicator is determined by entropy method. The relevant index system and weight results are shown in Table IV.

\section{The establishment of the partial least squares regression formula}

First, the integrated values of each target layer are derived from the weighted sum of the sub-indicators. The 3D ecological footprint of Shenyang is regarded as the dependent variable $(\mathrm{Y})$, the comprehensive value of each target layer is regarded as an independent variable, and the partial least-squares regression is performed. Our findings reveal that the fitting degree is relatively superior $\left(\mathrm{R}^{2}=0.9711\right)$, and thus we may determine 3 principal components accordingly and eventually propose the partial least-squares regression formula as shown below:
$\mathrm{Y}=0.1749 \mathrm{a}+0.0476 \mathrm{~b}+0.1268 \mathrm{c}-0.2986 \mathrm{~d}$

$+0.5385 \mathrm{e}+0.4329 \mathrm{f}-0.1592 \mathrm{~g}-0.0185 \mathrm{~h}$

where formula (5): a, b, c, d, e, f, g, h correspond to the 8 target layers in Table 4, respectively. According to formula (5), urban ecological construction, environmental pollution, population, economy, and consumption factors play a positive role in the development of ecological conditions, which constitute a major reason for the increased ecological footprints in Shenyang. Among these factors, urban ecological construction and environmental pollution have imposed the greatest impact on the Shenyang City's 3D ecological footprints mainly because the local heavy industries such as petrochemicals and iron and steel have consumed a large amount of crude oil and coal. Intensive energy consumption results in widespread and severe pollution, which gives rise to the natural material cost of the construction of the urban ecological environment as well as the environmental governance. Next, the impact posed by the population is also to blame for the increased ecological footprints. For example, the population of the Shenyang City in 2016 amounted to 6,453.6 thousand people, which increased by 829.2 thousand people in 10 years and led to the added ecological footprints. Consumption also constitutes a critical aspect affecting the ecological footprint. As people enjoy higher living standards, their corresponding ecological footprints also increase year by year. The regression coefficients are negative in terms of the foreign exchanges and trade, the environmental governance, and the structure of land use, indicating that these three factors are conducive to alleviating ecological deficits and improving the ecological environment. External exchanges and trade can relieve the ecological pressure faced by the Shenyang City, but may cause ecological pressure on its surrounding areas. The environmental governance is conducive to improving the environmental conditions in Shenyang and reducing the ecological deficit per capita.

\section{Analysis of the importance of various indicators on ecological footprint}

We clearly see the impact of each variable on the 3D ecological footprint, but we may not construe the contribution of each specific index to the $3 \mathrm{D}$ ecological footprint through the comprehensive evaluation and regression of the target layer. In order to further study the importance of various indicators on the impact of ecological footprint, we have measured the importance of all indicators according to the calculation of the importance index of PLS projection (Fig. 1). 
TABLE IV. THE FACTOR INDICATOR SYSTEM AND WEIGHTS FOR 3-DIMENSIONAL ECOLOGICAL FOOTPRINT IN SHENYANG

\begin{tabular}{|c|c|c|c|}
\hline Target layer & Index layer & Unit & Weight \\
\hline $\begin{array}{l}\text { Economic } \\
\text { development } \\
\text { index }\end{array}$ & $\begin{array}{l}\text { Yield of the primary industry } \\
\text { Yield of the secondary industry } \\
\text { Yield of the tertiary industry } \\
\text { Investment in fixed assets } \\
\text { Per capita GDP }\end{array}$ & $\begin{array}{l}\text { hundred million yuan } \\
\text { hundred million yuan } \\
\text { hundred million yuan } \\
\text { hundred million yuan } \\
\quad \text { Yuan per person }\end{array}$ & $\begin{array}{l}0.0879 \\
0.1737 \\
0.1991 \\
0.03087 \\
0.2310\end{array}$ \\
\hline $\begin{array}{l}\text { Consumption } \\
\text { index }\end{array}$ & $\begin{array}{l}\text { Per capita consumption expenditure } \\
\text { Retail sales of social consumer goods } \\
\text { Total imports and exports }\end{array}$ & $\begin{array}{l}\text { Yuan per person } \\
\text { hundred million yuan } \\
\text { hundred million yuan }\end{array}$ & $\begin{array}{l}0.2267 \\
0.3906 \\
0.3829\end{array}$ \\
\hline $\begin{array}{l}\text { Population } \\
\text { index }\end{array}$ & $\begin{array}{l}\text { Employees of the primary industry } \\
\text { Employees of the secondary industry } \\
\text { Employees of the tertiary industry } \\
\text { Total population } \\
\text { Population density }\end{array}$ & $\begin{array}{l}\text { ten thousand people } \\
\text { ten thousand people } \\
\text { ten thousand people } \\
\text { ten thousand people } \\
\text { people per } \mathrm{km}^{2}\end{array}$ & $\begin{array}{l}0.135 \\
0.289 \\
0.443 \\
0.017 \\
0.018\end{array}$ \\
\hline $\begin{array}{l}\text { Pollution } \\
\text { treatment } \\
\text { index }\end{array}$ & $\begin{array}{l}\text { Discharge standard rate of waste water } \\
\text { Disposal of the urban garbage } \\
\text { Removal of the Sulfur dioxide } \\
\text { Removal of smoke and dust } \\
\text { Dust removal } \\
\text { Comprehensive utilization ratio of industrial waste } \\
\text { Wastewater treatment rate } \\
\text { Investment in pollution control }\end{array}$ & $\begin{array}{l}\text { percent } \\
\text { hundred million tons } \\
\text { ten thousand tons } \\
\text { ten thousand tons } \\
\text { ten thousand tons } \\
\text { percent } \\
\text { percent } \\
\text { hundred million yuan }\end{array}$ & $\begin{array}{l}0.0006 \\
0.3085 \\
0.1497 \\
0.1492 \\
0.0026 \\
0.3633 \\
0.0170 \\
0.0094\end{array}$ \\
\hline $\begin{array}{l}\text { Foreign } \\
\text { exchange and } \\
\text { contact index }\end{array}$ & $\begin{array}{l}\text { freight transport } \\
\text { Passenger volume } \\
\text { Number of civilian vehicles } \\
\text { Road mileage } \\
\text { Total amount of post and Telecommunications }\end{array}$ & $\begin{array}{l}\text { ten thousand tons } \\
\text { ten thousand people } \\
\text { unit } \\
\text { km } \\
\text { ten thousand yuan }\end{array}$ & $\begin{array}{l}0.1070 \\
0.1332 \\
0.4953 \\
0.2414 \\
0.0232\end{array}$ \\
\hline $\begin{array}{l}\text { Urban ecological } \\
\text { construction }\end{array}$ & $\begin{array}{l}\text { Green coverage rate in built-up land } \\
\text { Public green space per capita } \\
\text { Green land }\end{array}$ & $\begin{array}{l}\text { percent } \\
\mathrm{m}^{2} \\
\mathrm{hm}^{2}\end{array}$ & $\begin{array}{l}0.0497 \\
0.9137 \\
0.0384\end{array}$ \\
\hline $\begin{array}{l}\text { Environment } \\
\text { pollution }\end{array}$ & $\begin{array}{l}\text { Waste water discharge } \\
\text { Exhaust emissions } \\
\text { Industrial waste emissions }\end{array}$ & $\begin{array}{l}\text { hundred million tons } \\
\text { hundred million tons } \\
\text { ten thousand tons }\end{array}$ & $\begin{array}{l}0.2329 \\
0.3920 \\
0.3741\end{array}$ \\
\hline $\begin{array}{l}\text { Land use } \\
\text { index }\end{array}$ & $\begin{array}{l}\text { Arable land } \\
\text { Per capita residential building area } \\
\text { Per capita road area } \\
\text { Construction land }\end{array}$ & $\begin{array}{l}\mathrm{hm}^{2} \text { per person } \\
\mathrm{hm}^{2} \text { per person } \\
\mathrm{hm}^{2} \text { per person } \\
\mathrm{hm}^{2} \text { per person }\end{array}$ & $\begin{array}{l}0.0103 \\
0.2148 \\
0.1130 \\
0.6619\end{array}$ \\
\hline
\end{tabular}

Judging from Fig. 1, we may conclude how each indicator contributes to the 3D ecological footprint. In particular, the indicators, including but not limited to the per capita public green area, industrial solid waste discharge, sewage treatment rate, highway mileage, total population, population and output value of the primary industry, population and output value of the second industry, construction area, investment in fixed assets, have imposed greater impacts on the Shenyang City's 3D ecological footprint. The per capita public green area index has imposed the largest impact on the City's 3D ecological footprint, followed by the industrial waste discharge index, which is consistent with the comprehensive evaluation results of the regression analysis.

\section{CONCLUSION}

In this paper, the improved 3D footprint model was applied to calculate the per capita 3D ecological footprint, per capita footprint, and the breadth 


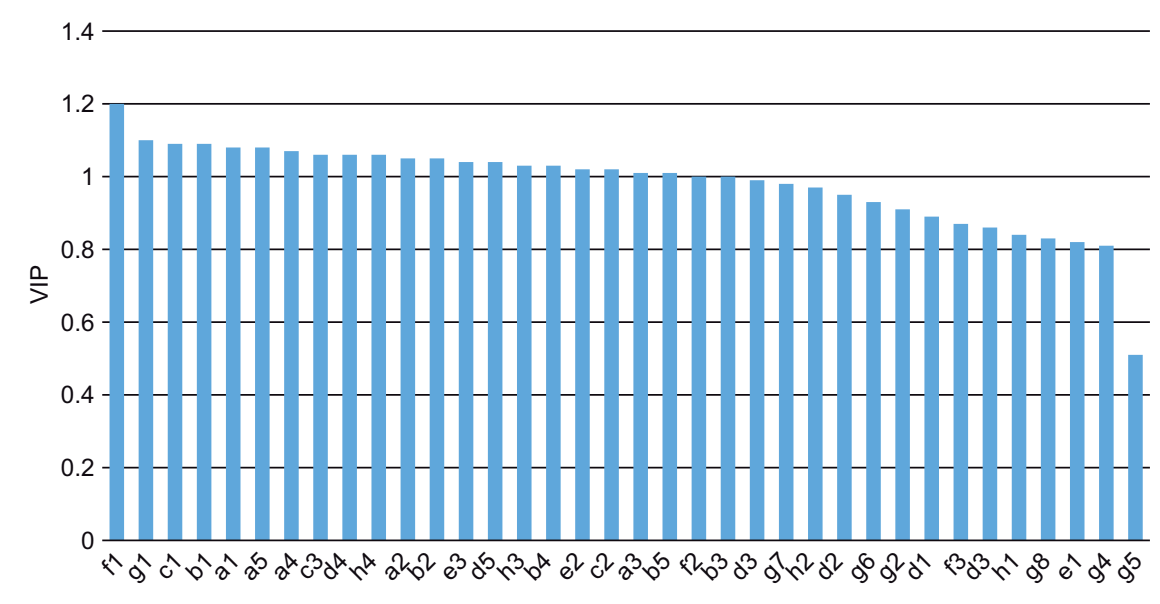

Fig.1. The VIP of the indicators for the influencing factors of the ecological in Shenyang

of Shenyang City's ecological footprint from 2006 to 2016. After a longitudinal analysis, we may conclude that the ecological deficit in Shenyang is significant and the ecological pressure is increasing. The economic and social development is mainly driven by the depletion of natural capital in other regions, among which the most unsustainable capital shall be the development of water resources as well as the resources occupied per capita for the arable land and the construction land. The analysis of the partial least-squares regression shows that the importance of the three-dimensional ecological footprint in the Shenyang City is: urban ecological construction $>$ environmental pollution $>$ population $>$ consumption $>$ economy. These factors constitute the major reasons for the increased ecological footprints in the City. Foreign exchanges and trade, environmental governance and structure of land use are conducive to alleviating the exacerbating ecological pressure. The importance of the analysis of the VIP values of various projection indicators is consistent with the overall evaluation results. In recent years, the Shenyang municipal government has attached greater importance to developing the eco-city and regards such an initiative as a vital way to address the environmental pollution and ecological damage during the urbanization drive. The Shenyang municipal government is committed to building the ecological city, developing urban green belts, increasing the coverage of green land, and managing environmental pollution, so as to create a greener Shenyang City. However, it is necessary for the government to improve the efficiency of urban ecological construction and to plan the use of urban land in a more reasonable manner.
Meanwhile, the government shall transform the energy structure and optimize the industrial structure. The government shall remain prudential while importing the agricultural and sideline products as well as the production-oriented consumer goods that may exert a great pressure on the local ecological environment. In addition, the government shall strive to reduce ecological deficits, and strike a balance among the population, the economy, the environment, and the harmonious development of resources.

\section{REFERENCES}

Ahamed A.J., Loganathan K., Ananthakrishnan S., Ahmed J. and Ashraf M.A. (2017). Evaluation of graphical and multivariate statistical methods for classification and evaluation of groundwater in alathur block, perambalur district, india. Applied Ecology and Environmental Research. 15 (3), 105-116.

Anees M.M., Qasim M. and Bashir A. (2017). Physiological and Physical Impact of Noise Pollution on Environment. Earth Science Pakistan. 1(1), 08-11.

Ashraf M.A., Hussin N.H. and Gharibreza M. (2017). Studies on the Removal of Heavy Metals from Aqueous Solution Using Immobilized Typha angustata L. Earth Science Pakistan. 1(1), 12-16.

Basheer A.O., Hanafiah M.M. and Abdulhasan M.J. (2017). A Study on Water Quality from Langat River, Selangor. Acta Scientifica Malaysia. 1(2), 01-04.

Borogayary B., Das A.K. and Nath A.J. (2018). Tree species composition and population structure of a secondary tropical evergreen forest in Cachar district, Assam. Journal Of Environmental Biology. 39 (1), 67-71. 
Cheung Y., Lam O., Lun S., Pang C., Wu K.W. and Leung W.K. (2017). Electrical Stimulation for Eggs and Semen on Tavhypleus Tridentatus Collected from Local Restaurants in Hong Kong. Malaysian Journal of Sustainable Agriculture. 1(2), 01.

Costanza R. and Daly H.E. (1992). Natural capital and sustainable development. Conservation Biology. 6 (1), 37-46.

Daly H.E. (1994). Operationalizing sustainable development by investing in natural capital[M]//Jannson A M, Hammer M,Folke C, et al. Investing in natural capital: The ecological economics approach to sustainability. Washington DC: Island Press. 22-37.

Dong Y., Zhi F.M. and Zhao Y.Y. (2012). Analysis of china supply and demand balance of ecological carrying capacity based on Ecological Footprint. Journal of natural resources. 27 (4), 614-624.

Du Y.Y., Peng J. and Gao Y. (2016). Sustainability evaluation of natural capital utilization based on a threedimensional ecological footprint model: A case study of the Beijing- Tianjin- Hebei Metropolitan region. Progress in Geography. 35 (10), 1186-1196.

Erb K.H. (2004). Actual land demand of Austria 1926 2000: a variation on Ecological Footprint assessments. Land Use Policy. 21 (3), 247-259.

Fang K. (2013). Ecological footprint depth and size: New indicators for a 3D model. Acta Ecologica Sinica. 33 (1), 267-274.

Fang K. (2014a). Changes in the spatial distribution of natural capital use among G20 countries from 1999 to 2008. Resources Science. 36 (4), 793-800.

Farley J. and Daly H. (2006). Natural capital: The limiting factor: Areply to Aronson, Blignaut, Milton and Clewell. Ecological Engineering. 28 (1), 6-10.

Fu H. and Liu X. (2017). Research on the Phenomenon of Chinese Residents' Spiritual Contagion for the Reuse of Recycled Water Based on SC-IAT. Water. 9 (84611). DOI: $10.3390 / \mathrm{w} 9110846$.

Gao W. and Wang W.F. (2017). The fifth geometricarithmetic index of bridge graph and carbon nanocones. Journal of Difference Equations and Applications. 23 (1-2SI), 100-109.

DOI: $10.1080 / 10236198.2016 .1197214$.

Grzeczka G. and Szymak P. (2016). The Hardware Implementation of Demonstrator Air Independent Electric Supply System Based on Pem Fuel Cell. Polish Maritime Research. 23 (4), 84-92.

Hui Z., Peiji S. and Juan H. (2013). Dynamic analysis of ecological footprint and ecological carrying capacity in Gansu Province. Arid Area resources and environment. 27 (10), 13-18.

Jin X.M. and Liu Q.K. (2017). Analysis of a land carrying capacity index based on an expanded 3-dimensional ecological footprint model: A case study of wenzhou. Acta Ecologica sinica. 37 (9).

Lijie L. and Feng Y. (2018). A Study on The Rhythm and Respiratory Characteristics of Zhuang Language. Acta Scientifica Malaysia. 2(1), 26-28.

Mana S.C.A., Hanafiah M.M. and Chowdhury A.J.K. (2017). Environmental characteristics of clay and claybased minerals. Geology, Ecology, and Landscapes. 1(3), 155-161.

Niccolucci V., Bastianoni S. and Tiezzi E.B.P. (2009). How deep is the footprint? A 3D representation. Ecological Modelling. 220 (20), 2819-2823.

Niccolucci V., Tiezzi E. and Pulselli F.M. (2012). Biocapacity vs ecological footprint of world regions: A geopolitical interpretation. Ecological Indicators. 16 (SI), 23-30.

Nordin N.F.H., Idris S.N.N.M., Nawi M.N.M., John A. and Chowdhury A.J.K. (2017). Pcb Biodegration Using Bacteria Isolated from Landfill Leachate. Science Heritage Journal. 1(2), 8-11.

Pe'Eri S., Madore B., Nyberg J., Snyder L., Parrish C. and Smith S. (2016). Identifying Bathymetric Differences over Alaska's North Slope using a Satellite-derived Bathymetry Multi-Temporal Approach. Journal of Coastal Research. (76), 56-63.

Roslan M.A.M., Mohamad M.A.N. and Omar S.M. (2017). High-Quality Dna From Peat Soil for Metagenomic Studies: A Minireview On Dna Extraction Methods. Science Heritage Journal. 1(2), 1-7.

Shenyang Municipal Bureau of statistics. (2017): Shenyang Statistics Yearbook, 2006-2016. Shenyang: Liaoning Statistical Publishing House.

Toum G.A.E., Yassin M.I., Dagash, and Mahagoub S.A. (2018). Nitrogen Use Efficiency of Three Maize (Zea Mays L.) Cultivars. Malaysian Journal of Sustainable Agriculture. 2(1), 12-14.

Wang H.W., Wu Z.B. and Mengjie. (2006). Linear and nonlinear methods for partial least squares regression. Beijing: National Defense Industry Press, 10-102.

World Wide Fund Fornature (WWF). (2013). Live plant report-Academic Edition 2005-World. http://www. Foot-printnet-workorg/. 12-20.

Xu Z.M., Cheng G.D. and Zhang Z.Q. (2001). Measuring sustainable development with the ecological footprint method: Take Zhangye prefecture as an example. Acta Ecologica Sinica. 21 (9), 1484-1493.

Yun G., Williams S. and Wenbin D. (2018). Integrating Two-Stage Up-Flow Anaerobic Sludge Blanket with A Single-Stage Aerobic Packed-Bed Reactorfor Raw Palm Oil Mill Effluent Treatment. Malaysian Journal of Sustainable Agriculture. 2(1), 15-18. 